\title{
Alexander von Humboldt's perceptions of colonial Spanish America
}

\author{
Sandra Rebok \\ Área de Cultura Científica, CSIC, Madrid. \\ srebok@orgc.csic.es
}

Dynamis

[0211-9536] 2009; 29: 49-72
Fecha de recepción: 27 de febrero de 2008

Fecha de aceptación: 9 de noviembre de 2008

SUMMARY: 1.-Introduction. 2.-Humboldt's perceptions of colonial societies. 2.1.-Venezuela. 2.2.-Cuba. 2.3.-Colombia. 2.4.-Ecuador. 2.5.-Peru. 2.6.-Mexico. 3.-Comparative studies and analyses. 4.-Differences found in Humboldt's regional descriptions. 5.-Possible explanation of differences. 6.-Conclusion.

ABSTRACT: This study presents an in-depth analysis of Alexander von Humboldt's descriptions and critical comments on the colonial society of the different regions he visited during his well-known expedition through the Americas (1799-1804). The criticisms of colonialism that he expressed, reflecting his personal convictions, have already been the focal point of many studies, but Humboldt also was able to offer a more differentiated assessment through comparisons of regional and local traditions and developments. This essay focuses on his personal diaries, which offer many interesting comments on colonial societies. These considerations and impressions made during the expedition are of particular scholarly value since they were not subject to censorship of any kind.

KEY WORDS: Alexander von Humboldt, Spanish America, travel narrative, colonial societies, perception of «the other».

PALABRAS CLAVE: Alexander von Humboldt, Hispanoamérica, narrativa de viajes, sociedades colonials, percepción de «el otro».

\section{Introduction $\left(^{*}\right)$}

At the time the Prussian scientist Alexander von Humboldt undertook his expedition through the Americas (1799-1804), accompanied by his French

$\left(^{*}\right)$ The study was originally conducted through a scholarship granted by the Alexander von Humboldt Foundation of Bonn and undertaken in the framework of a research project of the Spanish 
colleague and friend Aimé Goujand Bonpland ${ }^{1}$, the regions visited were still under Spanish rule, and so he became an eyewitness to the colonial systems on the eve of -in some cases during - their demise. Although the initial focus of his interest was generally with the description of natural phenomena, critical observations of the structures of colonial societies can be found throughout his work, often accompanied by comments about potential and desirable reforms. Thus, Humboldt's writings provide us with a valuable image of the Spanish colonial systems from the perspective of an external observer, a European who was undoubtedly influenced by the ideals of the French Revolution and the Enlightenment.

Until now, analyses of this aspect of Humboldt's work have been basically limited to certain perspectives. His work has been studied within the context of particular countries - for example, his relationship with specific colonial elites. His attitude towards, as well as his criticism of, colonialism and slavery, and his participation in the independence movement, have also been well documented. The research presented here, however, will provide an in-depth analysis of Humboldt's descriptions of, and comments on, the colonial reality in its past and contemporary contexts. This study will defend the hypothesis that although Humboldt expressed a general criticism of the colonial system - a criticism which was rooted in his personal convictions - he nevertheless offered a differentiated assessment of colonial societies based on comparisons of regional and local traditions and developments.

Therefore, this study provides a general analysis of both Humboldt's various descriptions of the structures of colonial societies in the regions he visited, as well as his interpretations of their similarities and differences.

A specific characteristic of Humboldt's perception of these aspects of colonial societies is his approach from several different points of view. He was constantly at pains to observe different facets of the colonial reality; as

Ministry of Science and Innovation project HUM2007-65125-C02-02/HIST. This article is a thoroughly revised and actualized version of my research which was first presented as a working paper in August 2002 at the International Seminar on the History of the Atlantic World, 1500-1825 at the Harvard University, Cambridge, USA. A preliminary and longer version of this paper has already been published in: Rebok, Sandra. A new approach: Alexander von Humboldt's perception of colonial Spanish America as reflected in his travel diaries. Itinerario. 2007; 31 (1): 61-88.

1. Aimé Bonpland, 1773 (La Rochelle, France)-1858 (Santa Ana, Argentina), was a French botanist and medical doctor. 
a result, his comments and descriptions embrace political, economic, social, and agricultural conditions. To evaluate his descriptions and recommendations it is necessary, therefore, not only to look at basic conditions themselves, but also to examine the situation in which Humboldt found himself as he encountered different groups within these societies. As his interaction was mainly with the ruling elite, his views were influenced by his need to maintain good relations and express any criticism with tact and diplomacy.

In this article, special emphasis will be placed on the fact that Humboldt seems to have read the signs of the expiration of the colonial regimes. Particular attention will also be paid to the kinds of comments and judgments of colonial societies which can be found in Humboldt's general works regarding his American expedition, namely his travel account entitled Relation historique, and especially his essay on Cuba, the Essai politique sur l'Ile de Cuba, as well as his text on New Spain, the Essai politique sur le Royaume de la Nouvelle-Espagne, in which he presents his official comments ${ }^{2}$. Nevertheless, it will be shown that his private writings, such as his diaries and unpublished essays, are far more revealing.

These diaries have only recently been published in their original languages: German and French, with only some parts translated into Spanish ${ }^{3}$. Therefore, integrating these valuable documents into the ongoing

2. Humboldt, Alexander von; Bonpland, Aimé. Personal narrative of travels to the equinoccial regions of the new continent, during the years 1799-1804. 7 vols., Amsterdam/New York: Da Capo Press Inc.; 1972. For this study, the original edition in French has been used: Humboldt, Alexander von; Bonpland, Aimé. Voyage aux régions équinoxiales du nouveau continent, fait en 1799, 1800, 1801, 1802, 1803 et 1804. Vol. I-XIII. Paris: Librairie Grecque-Latine-Allemande; 1816-1831; Humboldt, Alexander von. The Island of Cuba. A political essay. Kingston: Ian Randle Publishers; 2001; Humboldt, Alexandre de. Essai politique sur le royaume de la Nouvelle-Espagne du Mexique. 2 vols., Paris/Thizy: Éditions Utz; 1997.

3. The Alexander von Humboldt Research Center of the Academy of Science in Berlin was instituted in 1982 with the edition of the first volume - an anthology of his perceptions of certain topics - and was completed with the final publication in 2000: Faak, Margot, ed. Lateinamerika am Vorabend der Unabhängigkeitsrevolution. Eine Anthologie von Impressionen und Urteilen aus den Reisetagebüchern. Vol. 5, Berlin: Akademie Verlag; 1982; Faak, Margot, ed. Alexander von Humboldt. Reise auf dem Rio Magdalena, durch die Anden und durch Mexiko. Vol. 8, Berlin: Akademie-Verlag; 1986; Faak, Margot, ed. Alexander von Humboldt. Reise auf dem Rio Magdalena, durch die Anden und durch Mexiko. Vol. 9, Berlin: Akademie Verlag; 1990; Faak, Margot, ed. Alexander von Humboldt. Reise durch Venezuela. Vol. 12, Berlin: Akademie Verlag; 2000. A few years later, a missing part of his journal was found in Cracow and published by Dr. Ulrike Leitner from the Humboldt Research Center: Leitner, Ulrike ed. Alexander von Humboldt. Von Mexiko-Stadt nach Veracruz. Tagebuch. Berlin: Akademie-Verlag; 2005. Only the descriptions referring to Colombia, Peru, Ecuador and the Canary Island Tenerife have 
international research on Humboldt has generated fundamental problems of language. Without a doubt, Humboldt's diaries constitute an important basis for Humboldtian research in general, and in particular as it relates to «delicate» topics such as colonialism. The diaries allow scholars to incorporate interesting new perspectives into current research on Humboldt, and offer detailed impressions of his journey as it was being undertaken. These works also include valuable initial judgments and comments - spontaneous considerations which were not subjected to self-censorship.

The fact that Humboldt's descriptions of colonial societies in later works were influenced by developments in the former Spanish colonies, namely the independence movement and the creation of new American republics, grants further significance to the diaries for an analysis of the nature being undertaken here. These fundamental changes - which occurred just a few years after Humboldt returned from his expedition, while he was elaborating the results of his travels and publishing his famous work on America- particularly influenced the way he described the social aspects of the colonial systems he had recently encountered ${ }^{4}$. Moreover, the diaries provide us with the only complete description of Humboldt's American expedition, since the above-mentioned account of his travel, the Relation Historique, includes only the first third of his expedition, breaking off at the point when he left Cuba in March 1801.

In the first part of this study, Humboldt's perceptions of each region will be presented separately. In the second part, a general analysis of Humboldt's perceptions will be provided by examining the differences in his commentaries for each region, the possible motives for these differences, and Humboldt's own explanation for his divergent observations.

been published in Spanish: Humboldt, Alexander von. Extractos de sus diarios/Auswahl aus seinen Tagebüchern. Bogotá: Publicismo y Ediciones; 1982; Humboldt en el Perú. Diario de Alejandro de Humboldt durante su permanencia en el Perú (agosto a diciembre de 1802). Piura: Centro de Investigación y Promoción del Campesinado (CIPCA); 1991; Moreno Yáñez, Segundo E. Alexander von Humboldt: diarios de viaje en la Audiencia de Quito. Quito: Oxy; 2005; Puig-Samper, Miguel Ángel; Rebok, Sandra. Sentir y medir. Alexander von Humboldt en España. Aranjuez: Doce Calles; 2007, p. 239-297.

4. For example his work Relation Historique, an elaboration of the expedition recorded in his diaries, can be read as a political comment on the history of independence. For detailed information see: Holl, Frank. El científico independiente y su crítica al colonialismo. In: Miguel Ángel Puig-Samper, ed. Debate y perspectivas. Alejandro de Humboldt y el mundo hispánico. La modernidad y la Independencia Americana. Madrid: Fundación Histórica Tavera; 2000, p. 113-117. 


\section{Humboldt's perceptions of colonial societies}

At the time of Humboldt's expedition, the Spanish colonial territories in America through which he travelled were divided into the viceroyalties of New Spain, New Granada, and Peru. These colonial territories had already developed regional characteristics resulting from differences in the structure of colonial administration, local climate conditions, racial composition of the population, natural environment, mineral resources, autochthonous cultures, and many other factors.

This study places emphasis on the social aspects expressed in his contemplation of the structure of societies at the end of the colonial system. As these views are sometimes linked to other factors such as agriculture, trade, and so on, the various aspects cannot always be commented upon separately and will therefore be integrated.

To form an idea of Humboldt's general attitude toward colonialism and to generate a better understanding of his comments on local cases, it seems appropriate to consider an essay on colonialism found in his diaries and in which he expresses very well his sharp criticism of colonialism (he therefore kept it from publication) ${ }^{5}$ :

«D'où vient ce manque de moralité, d'où viennent ces soufrances, ce malaise dans lequel tout homme sensible se trouve dans les Colonies européennes? C'est que l'idée de la Colonie même est une idée immorale, c'est l'idée d'un pays qu'on rend tributaire à une autre, d'un pays dans lequel on ne doit parvenir quà un certain degré de prospérité, dans lequel l'industrie, les lumière ne doivent se répandre que jusquà un certain point.... Tout Gouvernement Colonial est un gouvernement de méfiance. On y distribue l'autorité non selon que la félicité publique des habitants l'exige, mais selon le soupçon que cette autorité peut s'unir, s'attacher trop au bien de la Colonie, devenir dangereux aux intérêts de la mère patrie».

This private document of Humboldt's is particularly revealing in that it demonstrates that his personal convictions were always based on moral considerations and that the well-being and happiness of the people were always foremost in his mind. Apart from its clear rejection of colonialism as a political and economical institution, the essay in his diary stands out for its in-depth analysis of colonialism's different facets, as well as its issues

5. Faak, n. 3, 1982, p. 63-64 
and the possible consequences which Humboldt foresaw. As he states, his sharp criticism did not refer exclusively to the Spanish colonies which he visited:

«Nullepart un Européen doit avoir plus honte de l'être que dans les Isles, soit Françaises, soit Anglaises, soit Danoises, soit Espagnol[e]s. Se disputer quelle Nation traite les Nègres avec plus d'humanité c'est se moquer du mot humanité et demander s'il est plus doux d'éventré ou écorché» 6 .

The following analysis places Humboldt's general criticism of colonialism or the institution of slavery to the side, and focuses specifically on the particular characteristics of the colonial societies which he noted in the different regions he visited. It follows the same geographic order as that of his journey through these regions, allowing an analysis of the chronological evolution of his perceptions.

\subsection{Venezuela}

What most attracted Humboldt's attention during his sixteen months' stay in the territory that today forms part of Venezuela was the exotic world of the Indians. After long and painstaking preparations for his expedition, Humboldt finally found himself in a tropical environment - the dream of his youth, evoked by the exotic travel literature current in those times and which fascinated him as a young man. He made contact with a number of Indian tribes and observed their different ways of life. On many occasions he comments upon his acquaintance with Indian cultures and makes reference to their character, particularly to the Indian indolence.

Apart from several anecdotes pertaining to the curious behaviour of the Indians, however, Humboldt provides detailed and extensive ethnographical descriptions in which he strives to present an objective and distinctive view of the Indians ${ }^{7}$. He describes their ways of life, their traditions, and different Indian languages. Beyond that he was also interested in the cultural differences between tribes in different areas, providing descriptions in which he reveals a certain preference for the tribe of the Caribes and mentioning

6. Faak, n. 3, 1982, p. 64

7. Faak, n. 3, 2000, p. 160-162, 254-255, 272-276, 306, 340-350. 
the consequences of tribal intermingling on physiognomy and character. Humboldt moreover provides detailed descriptions of the main obstacles which they faced in relation to colonial society, and consistently attempts to explain the Indian culture from an insider's point of view, illuminating the injustice of their treatment ${ }^{8}$.

This complete and in-depth description reveals his thorough knowledge of the anthropological issues of his era. His rejection of the current European discussion regarding the bon sauvage and the mal sauvage in preference for a distinction between free Indians and Indians who were consigned to living in the missions, merits special mention. Referring to this difference on many occasions, Humboldt reinforced the idea that their characters varied considerably and that the Indians in the missions had lost their natural personality. He states that their seeming stupidity and mistrust was adopted by them due to slave labour and the daily oppression which they faced in the missions ${ }^{9}$.

The missions formed part of Spanish American colonial society which Humboldt severely criticised. His description of Venezuela includes many allusions to the missions and the missionaries' despicable behaviour. $\mathrm{He}$ provides a thorough portrayal of the missionaries' violation of the law, and especially their imposition of religious dogma. He comments upon many examples of immoral behaviour — such as maintaining a «maitraisse», having children or selling alcohol- and mentions several cases of missionaries' abuse of power as they sought personal and financial gain. Above all, Humboldt highlights the monks' despotism and their treatment of the Indians. Apart from imposing Christian myths upon the Indians — something of which Humboldt strongly disapproved- he severely criticizes the fact that they were forced to work unnaturally hard in the missions, and were physically mistreated if they did not behave according to the missionaries' demands ${ }^{10}$.

Humboldt's relationship with the principle families of Caracas should also be mentioned, although Humboldt's Relation historique is a richer source of information than his diaries on this point ${ }^{11}$. In his narration he gives an

8. Faak, n. 3, 2000, p. 163, 303-304, 340-341, 349, 358.

9. Faak, n. 3, 2000, p. 341.

10. Faak, n. 3, 2000, p. 236, 259, 289-291, 304, 311, 378 .

11. This relationship is studied by Acuña Mendoza, Enrique. Alejandro de Humboldt y su relación con la élite criolla de la ciudad de Caracas, 1799-1800. Ensayos Históricos. Anuario del 
interesting view of the cultural life of pre-revolutionary Venezuelan society. He mentions the hospitality which he and his friend Bonpland enjoyed among the Venezuelan elite ${ }^{12}$. Regarding their intense preoccupation with culture, he writes about their relatively dynamic cultural life:

«J'ai trouvé dans plusieurs familles de Caracas le goût de l'instruction, la connaissance des chefs-d'oeuvre de la littérature françoise et italienne, une prédilection marquée pour la musique, qui est cultivée avec succès, et qui sert, comme fait toujours la culture des beaux-arts, à rapprocher les diverses classes de la societé» ${ }^{13}$.

In Caracas, Humboldt severely condemns - in a manner that extends to all of the other regions him visited - the cruel, inefficient, and arbitrary justice system, which he considered amongst the greatest evils of Spanish America. He comments upon the presence of the military stationed in Venezuela, the dissatisfaction of the soldiers due to maltreatment, lack of food, the arbitrariness of commanding officers, and the fact that they were not even paid appropriately.

In conclusion it can be said that Humboldt's depiction of Venezuela in his diaries emphasizes the sociological and anthropological aspects of life there. He seems to have been so fascinated by this new indigenous world and by the co-existence of different races, as well as the mixtures between them, that on occasion he even offers statistics regarding the composition of the population.

\subsection{Cuba}

Among the Spanish territories which Humboldt visited in America, Cuba was unique in the sense that there was no sign of an independence movement at the beginning of the nineteenth century. The social structure was completely dominated by large landowners, especially sugar planters whose slaves provided them with incalculable wealth. The Spanish government had convinced these landowners that independence would result in a slave 
revolt and the abolition of the institution of slavery, neither of which would be in their best interest.

It must be mentioned that the present analysis is based only on the published part of the diaries. For a long time, these short notes were considered to be the only comments made by Humboldt during his stay in Cuba which raised questions about his interest in this island, though he later dedicated a complete social, political, economic, and historical essay to it. It is only recently that Ulrike Leitner, from the Humboldt Research Center in Berlin, found in the Biblioteka Jagiellonska in Cracow 24 pages of unknown notes by Humboldt regarding his stay on the island of Cuba ${ }^{14}$. These documents are titled «Isle de Cuba. Antilles en general» and have not yet been published ${ }^{15}$.

Humboldt's criticism of the colonial administration, in particular, stands out in his commentary. He mentions the problem which Havana's disproportionate size had created for the rest of Cuba, and the corruption that predominated there due to the government's domination by large landowners and merchants. The infrequency, as well as the significance, of the comments and judgments made by Humboldt justifies extensive quotation:

«Die Zuckerkultur um Trinidad hat etwas zugenommen, man verschifft jährlich ein 4000 Cajas de azúcar; aber die Tyrannei, welche die Havanna auf den Rest der Insel ausübt, hindert alle Industrie. Da die Regierung in Havanna thront, den Rest der Insel nie sieht, da das Consulado aus Hacendados und Kaufleuten besteht, deren Interesse es ist, dass nur der Handel der Havanna floriere (...); in der Havanna, wo man für Geld sich jegliche Art von Expeditionspapiere schaffen kann, Zeugnisse, als habe man spanische Produkte geladen, als habe man Eisen und Sklaven; Papiere, die man von einem Schiff auf's andere überträgt (...) In Trinidad haben daher wegen Mangel der Abnahme Zucker keinen Preis; sie häufen sich an, während dass der Hacendado in der Havanna seine Produkte schon früher bezahlt erhält als er sie einärndtet.

14. Leitner, Ulrike. Anciennes folies neptuniennes! Über das wiedergefundene Journal du Mexique à Veracruz aus den mexikanischen Reisetagebüchern A. v. Humboldts. Humboldt im Netz. 2002, 3 (5); available at http://www.uni-potsdam.de/u/romanistik/ humboldt/ hin/ hin/hin5/ leitner.htm. Zeuske, Michael. Alexander von Humboldt y la comparación de las esclavitudes en las Américas. Humboldt im Netz. 2005, 7 (11), p. 68; available at http://www.uni-potsdam. de/u/romanistik/ humboldt/ hin/ hin11/inh_zeuske_1.htm.

15. An edition of these documents is being planned by Dr. Ulrike Leitner from the Academie of Science in Berlin and Prof. Michael Zeuske from the University of Cologne. 
Die Grösse Havannas ist schuld, dass die übrige Insel eine Wüste ist (...) Man denkt darauf, im Frieden unmittelbar Klage in Madrid zu führen (...) aber die Verwandten der Hacendados der Havanna, also die Gegenparthei, sind die reichsten, angesehensten, gewandtesten (...) Ausser der Ungerechtigkeit ist das ganze auch sehr unpolitisch. Die industrietötende Vertheuerung aller Lebensmittel, die Theuerung des Arbeitslohns, die Unmöglichkeit, sich lange als Stadt militärisch zu vertheidigen, Luxus, Sittenlosigkeit, Neigung nach ungesthümen Neuerungen, Gelbes Fieber-alles entsteht von der unnatürlich grossen Population der Havanna» ${ }^{16}$.

Besides warning of the danger of monoculture, Humboldt also refuted the conviction that a successful economy could only be realised through slave labour.

Comparing work on the huge plantations of Cuba with those on the small farms of Colombia, he pointed out the disadvantages of the Cuban model from an economic, as well as from a humanitarian, point of view. Since Cuban plantations produced nothing but sugar, the population could not survive without importing meat - they were, therefore, dependent upon external agents.

Referring to his second visit to Cuba near the end of his expedition, Humboldt included an interesting statement at the beginning of his description of a trip from Havana to Philadelphia:

«Nous partîmes le 29 avril 1804, tous très peu contents de notre second séjour de la Havane. Cet endroit nous parut agréable en 1800 venant des deserts de l'Orenoque. Il nous parut peu intéressant à présent venant du Mexique, où il y a peut-être un peu moins de libéralité d'idées (si l'on ose

16. Faak, n. 3, 2000, p. 47-48 (translation: «The sugar culture around Trinidad has increased a bit, every year about 4000 boxes of sugar are shipped; but the tyranny which Havana exerts on the rest of the island hinders all industry. The government is enthroned in Havana, never sees the rest of the island, because the Consulado consists of hacendados and merchants, whose interest it is that only the trade in Havana should flourish. (...) in Havana where for money one can acquire any kind of expedition document, certificates as if one would have loaded Spanish products, as if one had iron and slaves; papers that one transfers from one ship to the other (....) They think in peacetime about suing in Madrid (...) but the families of the hacendados in Havana — the opposite party, that is - are the richest, the most respected and the most skilful (....) Apart from the injustice, all of this is so very impolitic as well. The increase in the price of all foodstuffs — which kills industry - the increase in salaries, the impossibility of military defence of the city, the luxury, the immorality, the tendency towards impetuous innovations, the yellow fever - all results of the unnaturally large population of Havana». 
admettre des différences outre du infiniment petit!), mais au moins de grands établissements scientifiques. A la Havane toutes les conversations roulent autour du grand problème de faire avec le moins de Nègres le plus de pains de sucre en un jour, pourquoi le $\mathrm{M}[\mathrm{ar}]$ quis de X, favorisé par les négociants, vend son sucre à 17 et 19 quand un autre vend qu' à 14 et 16 . Avec cela rien que le résumé numérique, aucun intérêt technique, pas d'idée physique, pas de recherche de causes» ${ }^{17}$.

Here Humboldt clearly reveals that his perception of various places is to some extent influenced by the region from which he was coming.

In the published portion of his diaries, Humboldt generally presents quite a negative image of Cuba, and particularly of Havana. His criticism of Cuba is entirely in line with his personal convictions and seems to reveal his true opinion about this Caribbean island and its society. In Cuba, Humboldt was in contact almost exclusively with the colonial elite; landowners and sugar manufacturers comprised the colonial society with which he was confronted and, therefore, it is they who appear in his private annotations ${ }^{18}$. For obvious reasons his incisive criticisms are not to be found in his published works.

\subsection{Colombia}

In his description of Colombia, Humboldt continues to address topics concerning the Indian population, though much less intensely than in Venezuela. He comments mainly upon his encounters with Indians, and only infrequently mentions the injustice with which they are confronted ${ }^{19}$.

In this region, Humboldt's attention was dominated by the cultural influence of the first European settlers on local Indian culture. His criticism of the way Europeans settled so near Indian settlements, appropriating many of their cultural achievements without imparting their own knowledge and abilities, suggests that in the tropical regions Europeans adopted more from

\footnotetext{
17. Faak, n. 3, 2000, p. 394-395.

18. A more extensive study on the image of Cuba, found in the public and private works of Humboldt is presented in Rebok, Sandra. Alejandro de Humboldt en Cuba: reflexiones historiográficas. In: Josef Opatrný, ed. El Caribe Hispano. Sujeto y objeto en política internacional. Prague: Karolinum; 2001, p. 117-144.

19. Faak, n. 3, 1986, p. 77, 123, 143, 167.
} 
the Indians than vice versa. He also points out that due to their religious intolerance and imposition of laws, European settlers had limited the intellectual development of Indian culture. As a result, Humboldt considers the Indians to be in their original mental state, and therefore makes the claim that travelling in America was like being transported to an earlier epoch $^{20}$.

As usual, Humboldt focuses on miserable working conditions, especially of the oarsmen (bogas), who accompanied travellers on their treks down the rivers, and the porters (cargueros), who carried both cargo and people. He also paid particular attention to Colombia's scientific activity, and gives an interesting depiction of a struggle to institute a new philosophy based on the natural sciences at the University of Santa Fé, where young students were rebelling against the rules against rationalism imposed by the monks ${ }^{21}$.

In Colombia, Humboldt appears to have discovered an interest in the conquest and colonial history of the regions he visited. On several occasions he refers to the ancient civilizations of America, and gives lengthy descriptions of different aspects of these cultures ${ }^{22}$. Easily recalling his observations in Venezuela, Humboldt reaches clear conclusions regarding the difference between the so-called «highly developed» and the «less advanced», cultures of America- conclusions which were of interest in the anthropological debates of the nineteenth century:

«Auch sehen wir im Neuen Continent, dass vor der Conquista in den Ländern, wo kalte und heisse Erdstriche abwechseln (Neu-Granada, Mexico, Peru), die Einwohner zu höherer Geisteskultur gelangt waren als in den heissen, einförmigen Ebenen der Guayana, Caracas, am Orinoco, Río Negro und [Rio] Marañón, wo die Natur unerzwungen alles von selbst erzeugt, und wo die Gebirge nicht hoch genug sind, um ihre Bewohner zur Arbeit und zur Bekleidung zu zwingen ${ }^{23}$.

20. Faak, n. 3, 1986, p. 61, 153.

21. Faak, n. 3, 1986, p. 114-115.

22. Faak, n. 3, 1986, p. 94-97, 140.

23. Faak, n. 3, 1986, p. 97. Translation: «On the New Continent we also see that, before the Conquest, in those countries where cold and hot regions alternate (New Granada, Mexico, Peru), the inhabitants have reached a higher intellectual culture than on the hot and uniform plains of Guayana, Caracas, at the Orinoco, Rio Negro and [Rio] Marañón, where nature creates everything on her own without coercion, and where the mountains are not high enough to force their inhabitants to work or wear clothes». 


\subsection{Ecuador}

In Ecuador, Humboldt's attention appears to have been preoccupied by scientific excursions and, despite the fact that he does not give much space to describing creole society, the warm hospitality with which the travellers were greeted on the farms of the creole elite. A significant feature of Humboldt's description of Quito is the emphasis he places on the description of the churches and cultural achievements of this society, including the high quality of cultural events such as theatre plays ${ }^{24}$.

As far as the Indians are concerned, Humboldt reveals more interest in their ancient cultures - for which he expresses high appreciation on several occasions - and in the monumental remains which he discovered during his excursions ${ }^{25}$. Interestingly, he not only describes the Indians as victims, but adds sharp criticism of the caziques, which he describes as the «bloodsuckers» of the Indians who steal whatever the priests and corregidores leave behind ${ }^{26}$.

As usual, his descriptions of Ecuador include criticism of the missionaries, especially their lack of morality and the wealth which they had acquired. Humboldt suggests that this wealth should not be kept for personal purposes, but spent on social projects such as schools, universities, and hospitals ${ }^{27}$.

\subsection{Peru}

Similar to his comments on Ecuador, writing of Peru Humboldt shows more interest in - and more appreciation for- the pre-Hispanic Indian civilisation than the colonial one with which he was actually confronted. He describes at length, and in a somewhat admiring tone, the remains of the Indians' material culture, and returns to topics such as the conquest and destruction of these native societies. Nevertheless, his abiding interest

\footnotetext{
24. Faak, n. 3, 1986, p. 169-170.

25. Faak, n. 3, 1986, p. 229-232.

26. Faak, n. 3, 1986, p. 216.

27. Faak, n. 3, 1986, p. 235.
} 
in material culture does not prevent him from commenting upon the social injustice suffered by the Indians ${ }^{28}$.

Since by this time in his expedition he had already gained considerable experience with Indian culture, he dedicates more space to express his high regard of free Indians in contrast to those living in the missions ${ }^{29}$. Once again, he suggests that the negative character traits for which the Indians were known were directly related to their treatment in the missions:

«Que l'homme sauvage et libre est différent de celui des missions, esclave de l'opinion et de l'opression sacerdotale! Quelle vivacité, quelle curiosité, quelle mémoire, quelle rage de vouloir apprendre la langue espagnole et de se faire entendre dans la leur! Ces mêmes gens dans lesquels nous voyons une si grande nobilité d'esprit, ont des facultés intellectuelles, sont les plus indolents, les plus paresseux pour le travail. Ils sont couchés jour et nuit si la chasse ou l'ennemi ne les engagent pas de sortir. Mais cette indolence, dont des personnes peu philosophes ont tant parlé, ne tient certainement en rien à la stupidité. Elle annonce en eux aussi peu de stupidité que l'oisiveté de nos grands seigneurs ou nos savants, qui ne cultivent pas la terre, ne marchent jamais à pied, se font servir» ${ }^{30}$.

While travelling to Lima, Humboldt also notices that the Indians of warmer regions were much friendlier than those who lived in colder climates - an argument which he repeats elsewhere to express his feelings about the differences between Peruvian Indians and the Indians of Venezuela ${ }^{31}$.

Apart from these descriptions of the Indians, Humboldt, loyal to his humanitarian concerns, also criticizes a broad range of social problems in Peru, such as the corruption of the miners ${ }^{32}$. His diaries reveal little information, however, regarding his stay in Lima or his interaction with creole society ${ }^{33}$.

\footnotetext{
28. Faak, n. 3, 1986, p. 245 and ss., 250.

29. Faak, n. 3, 1986, p. 255-257.

30. Faak, n. 3, 1986, p. 256.

31. Faak, n. 3, 1986, p. 243.

32. Faak, n. 3, 1986, p. 265.

33. For more information about all kind of comments on Peru presented by Humboldt in his works see Nuñez, Estuardo; Peterson, Georg. El Perú en la obra de Alejandro de Humboldt. Lima: Librería Studium; 1971.
} 


\subsection{Mexico}

The fact that Humboldt visited Mexico when his expedition was almost nearing its end means that, on the one hand, he had already accumulated a wealth of observations of colonial societies, many aspects of which were therefore no longer new to him. As a result, the facets which he described at great length in Venezuela are scarcely commented upon in Mexico. On the other hand, his assimilation and experience with a wide variety of aspects of Spanish American colonial societies means that his observations in Mexico can be considered more elaborate and complex ${ }^{34}$.

Humboldt was fascinated by the capital, Mexico City, which in his opinion was even prettier and more elegant than most European cities, and much cleaner than Lima or Bogotá. However, he immediately describes the human misery that he sees on the streets, and comments on its cause, namely the unjust distribution of Mexican wealth. In this context, he intends to analyse why there is so much more poverty in Mexico than in Lima or Bogotá. The difference which Humboldt points out when comparing Mexico City to Lima is the number of Indians living in Mexico, and what to him appears to be their dull and indifferent character. In his comparison of Mexico to Bogotá, he finds the government and the population to be similar, and so offers an historical argument in which he blames ancient Mexican society with being more despotic, and the inequalities of society therefore more deeply-rooted. Later, when comparing the Mexican preHispanic cultures to those of Peru, he returns to the argument that the nature of ancient civilisations may have had an influence on contemporary colonial society ${ }^{35}$.

Humboldt appears to be relieved by the lack of black slaves in Mexico, although he comments that the situation of factory workers - mainly Indians - was not much different from slavery. He expresses his anger about their working conditions in strong terms, and concludes his description by suggesting that the government should deal with the matter immediately. Going so far as to take up the issue with the viceroy, Humboldt continues

34. The general view of Humboldt on Mexico and its colonial society is elaborated in: PuigSamper, Miguel Angel. El viajero científico: la visón de Humboldt sobre Nueva España. In: Salvador Bernabéu, Albert, ed. El paraíso occidental. Norma y diversidad en el México virreinal. México: Instituto de México en España; 1998.

35. Faak, n. 3, 1986, p. 322-323, 332. 
to address social injustice, describing the terrible situation of miners and Indians forced to toil digging drainage ditches ${ }^{36}$.

Years later in his published work on Mexico, Humboldt would focus even more attention on the huge social differences in the Mexican population, exposing a very critical stance:

«Le Méxique est le pays de l'inégalité. Nulle part peut-être il n'en existe une plus effrayante dans la distribution des fortunes, de la civilisation, de la culture du sol et de la population (...) Les Indiens mexicains, en les considérant en masse, présentent le tableau d'une grand misère. Relégués dans les terres les moins fertiles, indolents par caractère, et plus encore par suite de leur situation politique, les natifs ne vivent qu'au jour le jour» ${ }^{37}$.

This also explains Humboldt's plans in later years to return to Mexico - a desire that for many reasons never became a reality.

\section{Comparative studies and analyses}

Since Humboldt undertook his expedition through America on the eve of its independence, it is of special interest to observe how he described pre-revolutionary Spanish America, which signs of a coming revolution he detected and how he evaluated a given society's social problems ${ }^{38}$. In general, it can be said that he was quite cautious in his comments. On several occasions - apart from his numerous social critiques- Humboldt

36. Faak, n. 3, 1986, p. 361, 367-369, 388

37. Humbolt, n. 2, 1997, vol. 1, p. 133-134.

38. Furthermore, it is interesting to compare Humboldt's view on colonial Spanish America to his impressions regarding the free United States of America. Unfortunately, these impressions are not included in his travel diaries, which end with his arrival in this country. Nevertheless, numerous letters as well as some remarks in his published works give us a good idea of his attitude towards the U.S. For more information see: Schwarz, Ingo. Alexander von Humboldt's visit to Washington and Philadelphia, his friendship with Jefferson, and his fascination with the United States. Proceedings: Alexander von Humboldt's Natural History legacy and its relevance for today, Northeastern Naturalist. 2001; special issue 1, 43-56; Schwarz, Ingo. Alexander von Humboldts Bild von Latein- und Angloamerika im Vergleich. In: Reinhard, Wolfgang; Waldmann, Peter eds. Nord u. Süd in Amerika: Gegensätze. Gemeinsamkeiten. Europäischer Hintergrund. 1992; 2: 142-154; Rebok, Sandra. Two exponents of the Enlightenment: Transatlantic communication by Thomas Jefferson and Alexander von Humboldt. The Southern Quarterly. 2005-2006; 43 (4): 126-152. 
made reference to the events in Haiti and the possible influence or danger they might exert on the rest of colonial America. However, in his diaries there is no explicit comment or advice that reveals his opinion about the independence movements in the colonies he visited. That the Spanish colonies would find themselves in a much better economic situation if they achieved independence from the financial interests of the metropolis can only be deduced from his detailed economic analyses, his statistics of trade and his comments on population trends.

On the one hand, this is due to the fact that Humboldt always harboured a sense of gratitude towards Spain's King Carlos IV for granting permission for his expedition through the American colonies; on the other hand, this posture was also a function of his self-understanding as a scientist and his personal aims in undertaking his expedition. Humboldt quite clearly placed his focus on scientific objectives and was reluctant to risk realising his American project.

For these reasons, many of his critiques of society found in Humboldt's diaries fail to appear in his later published works. In some cases, diary entries were marked explicitly «never to be published». In the diaries, his fundamental criticism of colonialism is based on specific examples of oppression, corruption, and violations of human rights. A typical intellectual characteristic of Humboldt is that he never simply criticises what he found. Instead, his observations are based on an in-depth study of various issues, frequently accompanied by recommendations for solutions that either seemed more efficient or, in some cases, simply more humane. His writings contain important proposals for concrete reforms on a wide variety of different issues, such as the mono-cultivation of sugar, slavery, and the like.

In the aforementioned unpublished essay on colonialism, Humboldt also makes references to the difficulties that determined the relationship of the elites with the metropolis. Many of the evils he described had their origins in the metropolis, and the colonial administration was based on metropolitan laws. Apart from that, the permanent conflict with the metropolis created a certain attitude that Humboldt expressed in the following way:

«A mesure que la haine de la mère patrie augmente croît l'amour du sol natif. On cherche à se former de fausses idées sur tout. On trouve Caraccas et Lima plus cultivé que Madrid, on aime les autres nations ennemis de l'Espagne, on ne désire rien de plus ardemment que de voir Londres ou 
Paris et de enivré de la grandeur de la maison paternelle, et des égards par lesquels l'Aristocratie se fait valoir en Amérique, on se trouve déplacé, trop peu honoré et on retourne dans un pays où l'on dit vivre avec liberté parce qu'on peut y maltraiter impunément ses esclaves et insulter les blancs lorsqu'ils sont pauvres» ${ }^{39}$.

A further topic of interest which was expressed mainly in his diaries is Humboldt's negative perception of the way in which the ideas of the Enlightenment were put into practice in America. On several occasions he admits his disappointment that members of the creole elite talked about the freedom of mankind, about encyclopaedias, about European philosophers, and that in theoretical discussions they often even expressed revolutionary opinions, while in fact they were mainly interested in maintaining a situation that personally offered them many advantages ${ }^{40}$.

Since Humboldt's attitude toward the initial signs of the independence movement has been the topic of many studies, it will not be addressed at length here. In summary, it can be assumed that without explicitly approving of political revolution as a means of solving the social problems which he observed in Spanish America, to a certain degree Humboldt demonstrated a clear understanding of the circumstances that might have been leading events in that direction. Although in many ways Humboldt criticizes the social and political system in America and mentions a vast range of issues requiring an immediate solution, he never calls for armed revolution. On the other hand, Humboldt believes in the possibility and the necessity of obtaining social progress through reforms. Nevertheless, although the Prussian traveller continually claims to be more readily convinced by amendments than by revolutions, his critiques of the different facets of colonial society and the social injustice he discovered in Spanish America were interpreted and used in many cases to lend ideological support for these movements. ${ }^{41}$ In this regard, Alexander von Humboldt appeared to be the ideal person

\footnotetext{
39. Faak, n. 3, 1982, p. 64.

40. Faak, n. 3, 2000, p. 208.

41. Zeuske, Michael. Vom «buen gobierno» zur «besseren Regierung»? Alexander von Humboldt und das Problem der Transformation in Spanisch-Amerika. In: Zeuske, Michael; Schröter, Bernd, eds. Alexander von Humboldt und das neue Geschichtsbild von Lateinamerika. Leipzig: Universitätsverlag; 1992, p. 145-215 (186 and ss), analyzes the concept of revolution used by Humboldt. More information about Humboldt as a myth of the independence in: Zeuske, Michael. ¿Padre de la Independencia? Humboldt y la transformación a la Modernidad en la América española. In: Puig-Samper, Miguel Ángel, ed. Debate y perspectivas. Alejandro de
} 
to put forward as an intellectual leader, and he even became something of a cult figure and a hero of independence ${ }^{42}$.

\section{Differences found in Humboldt's regional descriptions}

Humboldt draws a portrait of the political and social situation of Spanish America that not only includes all of the important elements of each society but also offers insights into the differences between these societies, as well as conflicts among the various social groups within each population. His rich depiction of colonial society is not limited, however, to an isolated description of each social group, but also considers the networks that existed between different social classes, analyzing the interactions between them as well as their mutual influences. His attention is repeatedly drawn to the nature of accommodation between Indian inhabitants and European immigrants, but he also examines different cases of racial or cultural fusion.

Against this background it seems worthwhile to highlight the differences found in his descriptions, and to investigate whether or not Humboldt conducted a consistent assessment of the main aspects in each region, or if his perceptions differed from place to place.

Considerable disparities are apparent between his official and his unofficial texts that is to say, between the comments and critiques which he made of events as he experienced them, and those which he elaborated years later. A comparison of the descriptions and judgments found in Humboldt's diaries with those in his official works about America, such as his travel narratives and his essays on Cuba and Mexico, reveals that his initial, personal comments and verdicts are much more critical than what he decided to publish years later. As mentioned above, a fundamental reason for this cautious attitude was his sense of gratitude towards the Spanish government. The presence of critical considerations in his published work in spite of this appreciation, therefore, takes on an even higher value.

This kind of analysis also demands a consideration of the evident evolution of Humboldt's perception over the course of his five-year journey.

Humboldt y el mundo hispánico. La modernidad y la Independencia Americana. Madrid: Fundación Histórica Tavera; 2000, p. 67-99.

42. Lucena Giraldo, Manuel. El espejo roto. Una polémica sobre la obra de Alejandro de Humboldt en la Venezuela del siglo XIX. Dynamis. 1992; 12: 73-86. 
At the beginning of his expedition, Humboldt did not yet command an indepth understanding of the structure, function, and network of the different parts of colonial societies. Therefore, the first part of his diaries consists of relatively extensive descriptions of his scientific activities, especially regarding natural phenomena, although they also contain general views regarding the Indians, ethnographical descriptions, comments on the curiosity of their character and their behaviour, and his first impressions of the missions and the colonial cities. Later, Humboldt undertakes more complex and deeper analyses of the intricate composition of colonial societies.

With respect to the concrete differences between the various colonial societies of Spanish America, Humboldt makes a clear distinction between the Caribbean society of Cuba and other countries. While in Cuba there existed a clear separation between white and black populations - without an Indian presence- and the population was either free and, typically, wealthy, or enslaved and living under deplorable conditions, in Venezuela, Colombia, Mexico, and Ecuador the social system was far more complex. In the latter regions, the colonial societies could be considered more like caste societies, with major or minor Indian components, in which such factors as race, degree of liberty, and skin colour determined people's experiences. Slavery existed, but it was not as deeply entrenched an institution as it was in Cuba. Nevertheless, Humboldt points out that the Indians in the mines, who were forced into the so-called mita-system, lived under semislave conditions. These different societal structures are also reflected in Humboldt's descriptions.

Humboldt also devotes attention to the development of scientific and intellectual activity in general, as well as to the cultural progress he detected in the different regions. In the later elaboration of his first, spontaneous impressions, he declares:

«Quoique j'aie eu l'avantage que peu d'Espagnols ont partagé avec moi, d'avoir visité succesivement Caracas, la Havane, Santa-Fe de Bogota, Quito, Lima y Mexico, et que, dans ces six capitales de l'Amérique espagnole, ma position m'ait mis en relation avec des hommes de tous les rangs, je ne me permettrai pas de prononcer sur les différens degrés de civilisation auxquels la société s'est déjà élevée dans chaque colonie. Il est plus facile d'indiquer les nuances diverses de la culture nationale, et le but vers lequels se dirige de préférence le développement intelectuel, que de comparer et de classer ce qui ne peut être envisagé sous un même point de vue. Il m'a paru qu'il y a une tendence marquée pour l'étude approfondie des sciences à Mexico et 
à Santa-Fe de Bogota; plus de goût pour les lettres et tout ce qui peut flatter une imagination ardente et mobile, à Quito et à Lima; plus de lumières sur les rapports politiques des nations, des vues plus étendues sur l'état des colonies et des métropoles; à la Havane et á Caracas. Les communications multipliées avec l'Europe commerçante, et cette mer des Antilles que nous avons dêcrite plus haut comme une Méditerranée à plusieurs issues, ont influé puissament sur les progrés de la societé à lî̀le de Cuba et dans les belles provinces de Venezuela. Nulle part ailleurs, dans l'Amérique espagnole, la civilisation n'a pris une physionomie plus européenne» ${ }^{43}$.

In general, Humboldt identifies a difference between the cultures which developed in the tropical regions, and those which developed in colder regions, and proposes that the climate bears an influence on the population's character and way of life. Like many European scientists and philosophers, he distinguished between the ancient, advanced civilisations of the American Indian population, and particularly the cultural achievements of Peru and Mexico on the one hand, and the level of civilisation of the Indians which he encountered in Venezuela on the other.

\section{Possible explanation of differences}

In attempting to understand the personal and professional reasons for Humboldt's varying perceptions of the colonial societies of Spanish America, importance must be placed on his relationship with the colonial elites, since he interacted mainly with this group. Besides that, the differences in Humboldt's descriptions are in no small way due to the nature of his access to colonial society. Whether his access was mainly through the economic elite, as it was in Cuba, or through the Indians and missionaries, as in Venezuela and Colombia - or if he was more engaged in scientific activities, as in Mexico- obviously shaped his perceptions and influenced his judgments. In fact, Humboldt could only obtain fragmentary glimpses of different aspects of a society, as they were largely determined by his contacts and activities. Indeed, his diaries can be described more as an anthology of comments rather than a complete description of colonial reality. Undoubtedly, the length of time he spent in each region, the nature of his 
stay and the activities he undertook while there, as well as the development of his thinking during the expedition, all played an important role in shifting his perspective and determining how he articulated his ideas.

Humboldt's own explanation for his different perceptions of different regions of Spanish America also merits consideration. The principal reason he gave was the different origins of the European colonizers. Whereas a majority of the Europeans in Venezuela were Andalucians and Canary Islanders, the Castilians and Basques predominated in Mexico, and Buenos Aires was dominated by Catalunyans. In Humboldt's opinion, these cultures were essentially different, especially with regard to their aptitudes in agriculture, trade, and even their intellectual faculties. He was convinced that even after their relocation to the New Continent these groups preserved their national features ${ }^{44}$. Nevertheless, approximately twenty years later, after the political changes in the American colonies had already taken place, he modified his initial observation, confirming:

«In the interval of time which elapsed from the peace of Versailles to the revolution of St. Domingo, Havana has seemed ten times nearer to Spain than Mexico, Caracas or New Granada. During my residence in the colonies, fifteen years later, this apparent inequality had already become greatly diminished. At the present time, when the independence of the continental colonies, the importation of the products of foreign industry, and the outflow of the coinage of the new States, have increased the intercourse between Europe and America; when the distance is so much diminished by improvements in navigation, and the inhabitants of México, Colombia and Guatemala, rival each other in visiting Europe, the greater part of the old colonies of Spain, at least those washed by the Atlantic, seem also to be much nearer to our continent. Such are the changes, produced in a few years and which are extending in an extraordinary degree by the diffusion of knowledge, and by an activity which had been long repressed, that the contrasts of manners and civilization, which I had observed in the beginning of the present century, in Caracas, Bogotá, Quito, Lima, Mexico, and Havana, have become less apparent. The influence of the original Basques, Catalans, Gallegos and Andalusians is daily becoming less; and at this time it would be, perhaps, unjust to draw the distinctions of national refinement in the six capitals I have just named, as I had intended doing in another place» ${ }^{45}$.

\footnotetext{
44. See Minguet, Charles. Alejandro de Humboldt: Historiador y geógrafo de la América española (1799-1804). 2 vols., México: UNAM; 1969, vol. 1, p. 245-246.

45. Humbolt, n. 2, 2001, p. 153-154.
} 
Here Humboldt reveals yet another variable which he considered when determining national character: the geographical proximity of Spanish America's different regions to Europe. According to him, the possibility of communication with Europe, due to a region's geographic situation, could either increase or decrease the influence of intellectual currents coming from Europe. Whether a country looked towards Asia or -because of Atlantic contacts - towards Europe, influenced how isolated they would remain ${ }^{46}$. In his opinion the differences in the Indian societies had also been shaped by their contact with Europeans:

«Dieser Einfluss der Europäer auf den sonst so unbiegsamen Indianischen Charakter unendlich auffallend, wenn an [den] Indianer in [der] Provinz Quito und Mexico mit dem in Caracas, Cumana's und diese mit den Wilden am Atapapo und Orinoco vergleicht. Je länger das Zusammenwohnen mit [den] Europäern dauert, je mehr Mestizen entstanden...desto entfernter ist der Indianer von seinem ursprünglichen Charakter. In Caracas, Cumaná, Barcelona, wo [die] Bevölkerung minder als in Quito und Cusco, wenigstens [die] Einwohner minder aneinander gedrängt sind, ist [der] Indianer moralischer, natürlicher, den Wilden näher» ${ }^{47}$.

\section{Conclusion}

Concluding this analysis we can say that the observations of Alexander von Humboldt make it possible for scholars to elucidate fundamental aspects of colonial society during the period of social tension that preceded the Spanish-American revolutions for independence. In studying these societies and considering their different groups, interactions and problems, his diaries have proved an invaluable source of information. Finally, his judgments in this context are of a special value in offering European insight -in this context, an independent outsider's view - into the situation in Spain's

46. Minguet, n. 44, vol. 1, 241.

47. Faak, n. 3, 2000, p. 341-42 (translation: «This influence of the Europeans on the normally so inflexible Indian character is very striking if one compares the Indian in the province of Quito and Mexico with the one in Caracas, Cumana, and those with the savages at the Atapapo and Orinoco. The longer the cohabitation with the Europeans, the more mestizos were born (...), the further the Indian is from his original character. In Caracas, Cumana, Barcelona, where there is less population than in Quito or in Cusco, where at least the inhabitants live less crowded together, the Indian is more moral, more natural, closer to the wilds»). 
American empire. Humboldt's texts bear the testimony of both a scholar -instructed in several branches of the most advanced sciences of his era- and a diplomat, expressed by an in-depth knowledge of international events in Europe and their influence on America. In this sense Humboldt stands out as both a contemporary of the Enlightenment and a member of the European elite who, at the beginning of the nineteenth century, placed special importance on culture and science. Together, these factors endowed Humboldt with the ability to provide in-depth observations of the colonial societies of Spanish America. 